\title{
Identification of endothelial selectin as a potential prognostic marker in breast cancer
}

\author{
WEI ZHANG ${ }^{1 *}$, ZHICHAO ZUO $^{1 *}$, XIANGYANG HUANG ${ }^{*}$, JUNJIE LIU $^{2 *}$, GUANQIAO JIN $^{1}$ and DANKE SU ${ }^{1}$ \\ Departments of ${ }^{1}$ Radiology and ${ }^{2}$ Ultrasound, Affiliated Tumor Hospital of Guangxi Medical University, \\ Nanning, Guangxi 530021, P.R. China
}

Received August 23, 2017; Accepted April 19, 2018

DOI: $10.3892 / \mathrm{ol} .2018 .8570$

\begin{abstract}
Endothelial selectin (ELAM1 or CD62E) has been previously reported as being associated with the prognosis of multiple types of cancer. However, its prognostic value in breast cancer $(\mathrm{BC})$ remains unclear. The aim of the present study was to investigate the prognostic value of ELAMI mRNA expression in BC tissue. The prognostic value of ELAM1 mRNA was assessed in patients with BC using the Kaplan-Meier plotter (KM-plot) database. The KM-plot generated updated ELAM1 mRNA expression data and survival analysis from a total of 3,951 patients with BC, gathered from 35 datasets. Low expression of ELAM1 mRNA was correlated with a poorer overall survival in 1,402 patients with $\mathrm{BC}$ followed for 20 years [hazard ratio (HR), 0.71; 95\% confidence interval (CI), 0.57-0.88; log-rank $\mathrm{P}=0.0016]$. Low expression of ELAM1 was also correlated with poorer relapse-free survival (HR, 0.69; 95\% CI, 0.62-0.77; log-rank $\mathrm{P}=2.2 \mathrm{e}-11)$ in 3,951 patients and poorer distant metastasis-free survival (HR, 0.79; 95\% CI, 0.65-0.96; log-rank $\mathrm{P}=0.02$ ) in 1,746 patients with $\mathrm{BC}$ followed for 20 years. Results from the Metabolic gEne RApid visualizer database indicated that ELAM1 mRNA expression was elevated in normal tissue. The results of the present study suggest that ELAM1 mRNA is a
\end{abstract}

Correspondence to: Dr Danke Su or Dr Guanqiao Jin, Department of Radiology, Affiliated Tumor Hospital of Guangxi Medical University, 71 Hedi Road, Nanning, Guangxi 530021, P.R. China

E-mail: sudanke2012@163.com

E-mail: jgq2011@163.com

*Contributed equally

Abbreviations: $\mathrm{BC}$, breast cancer; $\mathrm{HR}$, hazard ratio; CI, confidence interval; KM-plot, Kaplan-Meier plotter; OS, overall survival; RFS, relapse-free survival; DMFS, distant metastasis-free survival; PPS, post-progression survival; ER, estrogen receptor; PR, progesterone receptor; HER2, human epidermal growth factor receptor; TP53, tumor protein $\mathrm{p} 53$

Key words: breast cancer, ELAM1, prognosis, Kaplan-Meier plotter, marker potential prognostic and metastatic marker in patients with BC.

\section{Introduction}

Breast cancer (BC) is the most common female cancer worldwide and the second leading cause of cancer-related death. Its etiology involves genetic and environmental factors. Metastasis is the major challenge in BC therapy (1). Gene therapy can treat, cure, or prevent a particular disease as the transfer of foreign genetic materials to a patient. Solid tumor tissues can be significantly enhanced the targeting ability of delivery systems to solid tumors (2). Recent studies have reported that mRNA shows high potential in gene therapy $(2,3)$. However, the gene therapy of endothelial selectin (also known as ELAM1 or CD62E) mRNA remains unclear in BC.

Surgical resection is potentially curative, but its prognosis is often unpredictable. The evaluation of prognosis in patients with $\mathrm{BC}$ who have undergone surgical resection is essential for chemotherapy planning. A major obstacle is the lack of predictive tools capable of estimating post-treatment prognosis $(4,5)$. The results of recent studies have shown that no single method can fully predict prognosis in patients with $\mathrm{BC}$; scholars have made sustained efforts to identify the most useful approaches (6-9), including examination of the predictive value of numerous genes $(10,11)$.

Intercellular adhesion molecules play important roles in tumor progression and metastasis, which have traditionally been regarded as important indicators of tumor prognosis (12-17). These complex processes involve several mechanisms, such as uncontrolled cell growth, intercellular interactions, leukocyte changes, adhesion of vascular endothelium, and the induction of neoangiogenesis (18-20). In BC, serum levels of adhesion molecules have been correlated with tumor progression and metastasis (12-17,21-23).

ELAM1 is a member of the selectin adhesion molecule family with a molecular weight of 97-115 kDa, which is expressed on endothelial cells activated by cytokines $(4,6,24,25)$. It mediates the rolling of neutrophils and leukocytes on the surfaces of endothelial cells. In previous studies, ELAM1 levels were elevated in patients with hepatocellular, prostate (26), renal (27), colon (28), gastrointestinal, and ovarian cancers (29) and BC (19,25,30,31). Most research 
to date, however, has focused on soluble ELAM1. The prognostic implications of ELAM1 mRNA in BC remain unclear.

An online survival analysis tool that can be available to evaluate the prognostic implications of single genes in BC $(11,32,33)$. We used an integrative data analysis tool (http://kmplot.com/) to confirm the predictive values of proliferation-related ELAM1 genes. Data entered into the Kaplan-Meier plotter (KM-plot) were extracted from the Gene Expression Omnibus (GEO; https://www.ncbi.nlm.nih .gov/geo/) database. At present, the KM-plot database can be used to evaluate the prognostic values of 54,675 genes using 10,461 cancer samples from patients $(5,143$ breast, 2,437 lung, 1,816 ovarian, 1,065 gastric cancer; mean follow-up periods of $69,49,40$, and 33 months, respectively). Survival analyses conducted with data on individual genes can be validated by KM-plot, and KM-plot have been utilized by lots of genes in ovarian cancer $(34,35)$, BC (11,36-41), gastric cancer (42), and non-small cell lung cancer $(43,44)$.

In this study, the prognostic value of individual ELAMI was assessed in patients with BC using KM-plot.

\section{Materials and methods}

Kaplan-Meier survival analysis. An online KM-plot database can be utilized to identify the relevance of individual ELAMI mRNA expression in survival analyses, including the examination of overall survival (OS), relapse-free survival (RFS), distant metastasis-free survival (DMFS), and post-progression survival (PPS). The KM-plot database is handled by a MySQL server, which synchronously integrates gene expression and clinical data. Survival curves are calculated using the 'survival' package, and the number-at-risk is displayed below the main plot. Hazard ratios (HRs), 95\% confidence intervals (CIs), number of risk, and log-rank P-values are also indicated on the webpage (11). Number of risk can be interpreted as the number of surviving patients. HR is the ratio of the hazard rates corresponding to the conditions described by two levels of an explanatory variable.

Construction of BC microarray database. The database for this study was constructed using gene expression data and survival information from 3,951 patients with BC followed for 20 years. These data were downloaded from GEO, the Cancer Genome Atlas (https://cancergenome. nih.gov/), the European Genome-Phenome Archive (https://ega.crg.eu/), and PubMed (https://www.ncbi. nlm.nih.gov/pubmed/). Briefly, ELAM1 was entered into Affymetrix ID choosing the probe set 206211_at (ELAMI) in the KM-plot database (http://kmplot.com/analysis/index. $\mathrm{php}$ ? $\mathrm{p}=$ service \& cancer $=$ breast) to obtain KM-plots. The analysis determines whether high (above the median) and low (below the median) ELAM1 mRNA expression are associated with significantly different prognoses in patients with BC. We then conducted stratified analyses to evaluate correlations with estrogen receptor (ER) status, progesterone receptor (PR) status, human epidermal growth factor 2 (HER2) status, lymph node status, pathological grade, tumor protein p53 (TP53) status, intrinsic subtype, and Pietenpol subtype in patients with $\mathrm{BC}$.
Cancer and normal tissue analysis. The Metabolic gEne RApid Visualizer (MERAV) website (http://merav.wi.mit. edu/SearchByGenes.html) was developed to provide additional advanced web-based tools for the analysis of gene expression in tumor and normal tissues (45). MERAV is linked to two other databases, the National Center for Biotechnology Information's Entrez Gene database (http://www.ncbi.nlm .nih.gov) and the Kyoto Encyclopedia of Genes and Genomes (http://www.genome.jp/kegg/) (46), which allows the user to acquire more comprehensive information for each gene selected. We further identified ELAMI mRNA expression in BC and normal tissues using the MERAV database. We conducted a search for the ELAM1 gene in MERAV, which automatically generates boxplots of the data.

Statistical analysis. Univariate survival analyses were conducted using Kaplan-Meier survival curves. HRs with 95\% CIs were calculated using a Cox proportional-hazards regression model to evaluate survival ratios. Stratified analyses were conducted to further confirm the correlations of individual ELAM1 with other clinicopathological features. $\mathrm{P}<0.05$ was considered to indicate a statistically significant difference.

\section{Results}

Data sources. We identified all together 3,951 patients in the GEO, TCGA, EGA, and PubMed. There were no samples repeatedly published (11). The validation was performed on microarrays which were previously published in following datasets: E-MTAB-365, E-TABM-43, GSE11121, GSE12093, GSE12276, GSE1456, GSE16391, GSE16446, GSE16716, GSE17705, GSE17907, GSE18728, GSE19615, GSE20194, GSE20271, GSE2034, GSE20685, GSE20711, GSE21653, GSE2603, GSE26971, GSE2990, GSE31448, GSE31519, GSE32646, GSE3494, GSE37946, GSE41998, GSE42568, GSE45255, GSE4611, GSE5327, GSE6532, GSE7390 and GSE9195.

Survival analysis. The KM-plot curves showed that low expression of ELAM1 mRNA was correlated with worse OS in 1,402 patients with $\mathrm{BC}$ followed for 20 years $(\mathrm{HR}=0.71$; 95\% CI, 0.57-0.88; log-rank $\mathrm{P}=0.0016$; Fig. 1A). Low expression of ELAM1 mRNA was correlated strongly with worse RFS (HR=0.69; 95\% CI, 0.62-0.77; log-rank $\mathrm{P}=2.2 \mathrm{e}-11)$ in 3,951 patients with $\mathrm{BC}$ and worse DMFS $(\mathrm{HR}=0.79 ; 95 \% \mathrm{CI}$, $0.65-0.96$; log-rank $\mathrm{P}=0.02$ ) in 1,746 patients with $\mathrm{BC}$ followed for 20 years (Fig. 1B and C).

PPS showed no significant difference in the survival analysis or stratified analysis of 414 patients with BC (Fig. 1D and Table I). Stratified analyses further confirmed the correlations of individual ELAM1 with other clinicopathological features. ELAM1 mRNA expression was elevated in normal tissues (Fig. 2).

In the analysis stratified by OS, individual ELAM1 mRNA expression was associated with pathological grade 2 in 387 patients $(\mathrm{HR}=0.63$; 95\% CI, 0.41-0.98; log-rank $\mathrm{P}=0.038$; Table II). No other stratum of OS showed a significant association.

In the analysis stratified by RFS, high expression of ELAM1 significantly decreased the risk of metastasis among patients with ER positivity $(\mathrm{HR}=0.65, \log$-rank 

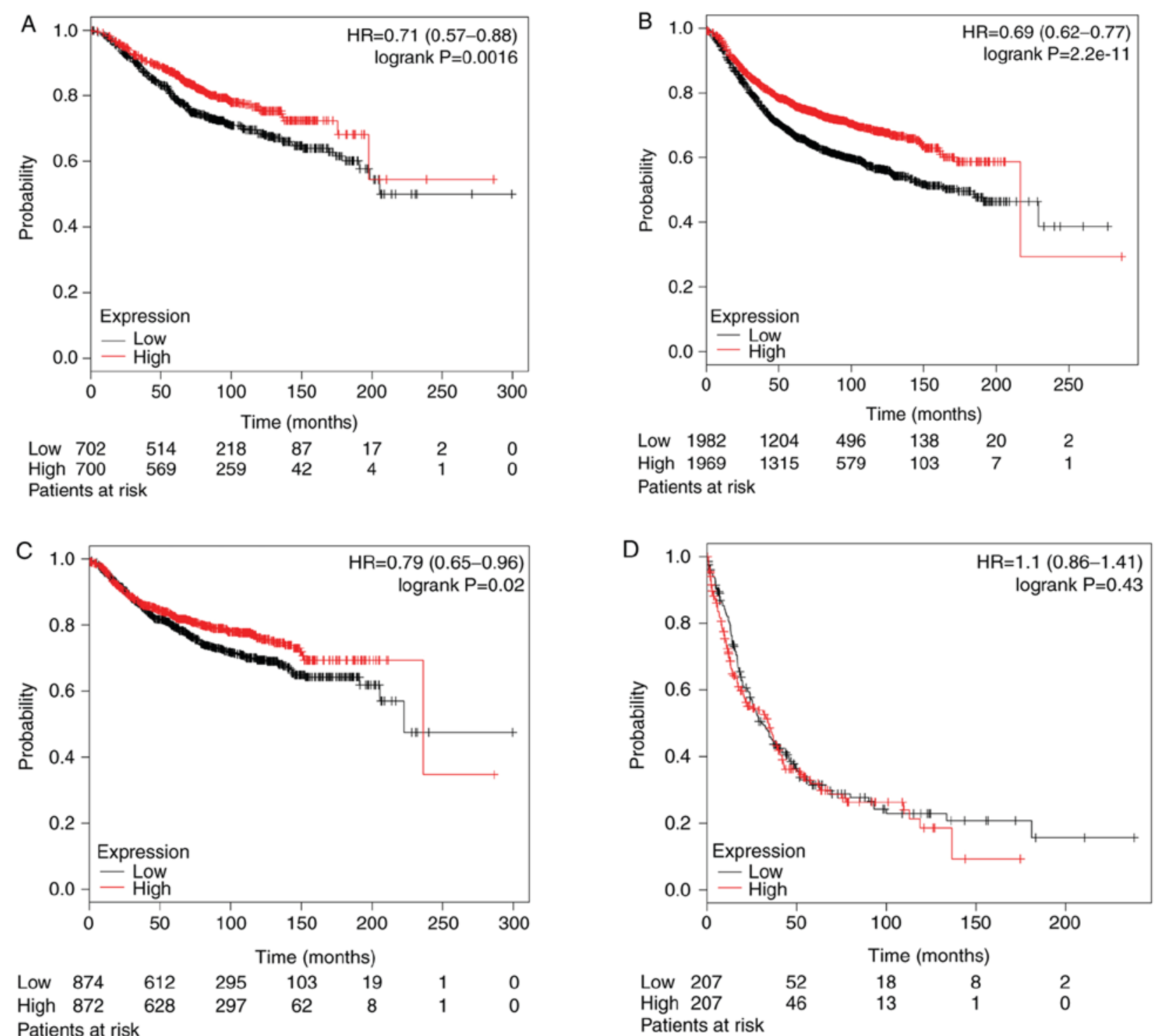

Figure 1. The prognostic value of ELAM1 expression. Curves for (A) overall survival ( $\mathrm{n}=1,402)$, (B) relapse-free survival ( $\mathrm{n}=3,951)$, (C) distant metastasis-free survival $(\mathrm{n}=1,746)$ and (D) post-progression survival $(\mathrm{n}=414)$. The small vertical bars cross the curve indicate censoring. The desired Affymetrix ID is available: 206211_at (ELAM1, also known as CD26E). Data were analyzed using the Kaplan Meier Plotter (http://kmplot.com/). HR, hazard ratio.

$\mathrm{P}=5.2 \mathrm{e}-07)$, ER negativity $(\mathrm{HR}=0.79, \log$-rank $\mathrm{P}=0.041)$, PR positivity $(\mathrm{HR}=0.58$, log-rank $\mathrm{P}=0.0029)$, HER2 negativity $(\mathrm{HR}=0.53, \log$-rank $\mathrm{P}=3.5 \mathrm{e}-06)$, lymph node positivity ( $\mathrm{HR}=0.82$, log-rank $\mathrm{P}=0.046)$, lymph node negativity ( $\mathrm{HR}=0.73$, log-rank $\mathrm{P}=3 \mathrm{e}-04)$, pathological grades 2 $(\mathrm{HR}=0.77, \log$-rank $\mathrm{P}=0.034)$ and $3(\mathrm{HR}=0.76, \log$-rank $\mathrm{P}=0.013)$, the basal subtype $(\mathrm{HR}=0.67, \log$-rank $\mathrm{P}=0.0019)$, the luminal A subtype ( $\mathrm{HR}=0.64, \log$-rank $\mathrm{P}=3.5 \mathrm{e}-07)$, the luminal $B$ subtype $(H R=0.69, \log$-rank $P=0.0001)$, the TP53 wild type $(\mathrm{HR}=0.56, \log$-rank $\mathrm{P}=0.0073)$, and the immunomodulatory subtype $(\mathrm{HR}=0.56, \log$-rank $\mathrm{P}=0.0073$; Table III).

Comparison of cancer and normal tissue. The analysis stratified by DMFS demonstrated that low expression of individual ELAM1 mRNA significantly increased the risk of metastasis in patients with $\mathrm{ER}$ positivity $(\mathrm{HR}=0.67, \log$-rank $\mathrm{P}=0.02)$ and HER2 negativity (HR=0.22, log-rank $\mathrm{P}=0.0027$; Table IV). No other DMFS stratum showed a significant association.

\section{Discussion}

Multiple studies have indicated that high expression of ELAM1 is associated with significantly worse OS and an increased risk of metastasis in patients with hepatocellular carcinoma (47), prostate cancer (26), colorectal cancer $(28,48,49)$, and BC $(29,50)$. Research conducted by Zhang and Adachi (51) suggested that soluble ELAM1 expression is a prognostic factor for advanced tumors. However, previous studies examined soluble ELAM1 and/or had in vitro designs. In vivo, the plasma and serum levels of ELAM1 are influenced by conditions such as diabetes, arthritis, and inflammation $(52,53)$. Multiple studies $(19,22,54)$ have shown that soluble ELAM1 is not a significant prognostic factor for BC metastasis. Muraki et al (55) demonstrated that high levels of soluble ELAM1 had an anti-tumoral effect in renal cell carcinoma (RCC) and significantly decreased the risk of RCC metastasis.

In the present study, we assessed the predictive significance of ELAM1 mRNA in 3,951 patients with BC. Their tumor 
Table I. Correlation of endothelial selectin expression with post-progression survival in patients with breast cancer.

\begin{tabular}{|c|c|c|c|c|c|}
\hline Variable & Group & Cases & HR & $95 \% \mathrm{CI}$ & $\begin{array}{c}\text { Log-rank } \\
\text { P-value }\end{array}$ \\
\hline \multirow[t]{2}{*}{ ER status } & Positive & 173 & 0.95 & $0.64-1.42$ & 0.81 \\
\hline & Negative & 100 & 0.74 & $0.44-1.25$ & 0.26 \\
\hline \multirow[t]{2}{*}{ PR status } & Positive & 13 & N/A & N/A & N/A \\
\hline & Negative & 17 & N/A & N/A & N/A \\
\hline \multirow[t]{2}{*}{ HER2 status } & Positive & 33 & 0.85 & $0.32-2.24$ & 0.74 \\
\hline & Negative & 39 & 1.16 & $0.43-3.13$ & 0.76 \\
\hline \multirow[t]{2}{*}{ Lymph node status } & Positive & 128 & 1.1 & $0.70-1.72$ & 0.68 \\
\hline & Negative & 165 & 0.97 & $0.63-1.49$ & 0.89 \\
\hline \multirow[t]{3}{*}{ Grade } & 1 & 34 & 0.81 & $0.30-2.22$ & 0.69 \\
\hline & 2 & 128 & 1.18 & $0.73-1.92$ & 0.49 \\
\hline & 3 & 165 & 1.01 & $0.69-1.48$ & 0.96 \\
\hline \multirow[t]{4}{*}{ Intrinsic subtype } & Basal & 64 & 0.93 & $0.52-1.66$ & 0.79 \\
\hline & Luminal A & 179 & 0.99 & $0.68-1.47$ & 0.98 \\
\hline & Luminal B & 134 & 1.10 & $0.71-1.69$ & 0.67 \\
\hline & HER2+ & 37 & 1.31 & $0.62-2.76$ & 0.48 \\
\hline \multirow[t]{2}{*}{ TP53 status } & Mutated & 34 & 0.68 & $0.28-1.65$ & 0.39 \\
\hline & Wild type & 62 & 1.31 & $0.66-2.61$ & 0.43 \\
\hline \multirow[t]{6}{*}{ Pietenpol subtype } & Basal-like 1 & 171 & 0.90 & $0.56-1.45$ & 0.66 \\
\hline & Basal-like 2 & 76 & 1.09 & $0.54-2.21$ & 0.81 \\
\hline & Immunomodulatory & 17 & N/A & N/A & N/A \\
\hline & Mesenchymal & 24 & 0.95 & $0.39-2.33$ & 0.91 \\
\hline & Mesenchymal stem-like & 4 & $\mathrm{~N} / \mathrm{A}$ & N/A & N/A \\
\hline & Luminal androgen receptor & 32 & 0.46 & $0.20-1.07$ & 0.06 \\
\hline
\end{tabular}

HR, hazard ratio; CI, confidence interval; ER, estrogen receptor; PR, progesterone receptor; HER2, human epidermal growth factor 2; TP53, tumor protein $\mathrm{p} 53$; N/A, not available.

specimens were analyzed using the probe set 206211_at. We found that high expression of ELAM1 mRNA was associated significantly with increased OS, RFS, and DMFS in patients with $\mathrm{BC}$, contrary to previous research results for soluble ELAM1 $(12-17,19,21,22,25,47,51)$. The stratified analysis showed that high expression of ELAM1 mRNA was associated with better OS in patients with grade 2 BC. Low ELAM1 mRNA expression was correlated with metastasis in ER-positive and HER2-negative patients. Furthermore, the results from the MERAV and KM-plot databases were consistent. The results of previous studies have rarely been reported. Our results show that ELAMI mRNA is an anti-oncogene that plays an important role in the evaluation of $\mathrm{BC}$ prognosis. Thus, the prognostic values of ELAM1 mRNA in different tumors differ, which should be kept in mind.

The difference in findings on the association of ELAMI mRNA expression and ELAM1 plasma concentration with BC prognosis $(21,22,25,29,50,51)$ is likely attributable to the following factors. Adhesion molecules of activated endothelial cells have dual roles in tumor growth and metastasis (53). They are part of a host immune response, which explains the sustained elevation of serum ELAM1 levels in patients with cancer. Shedding of adhesion

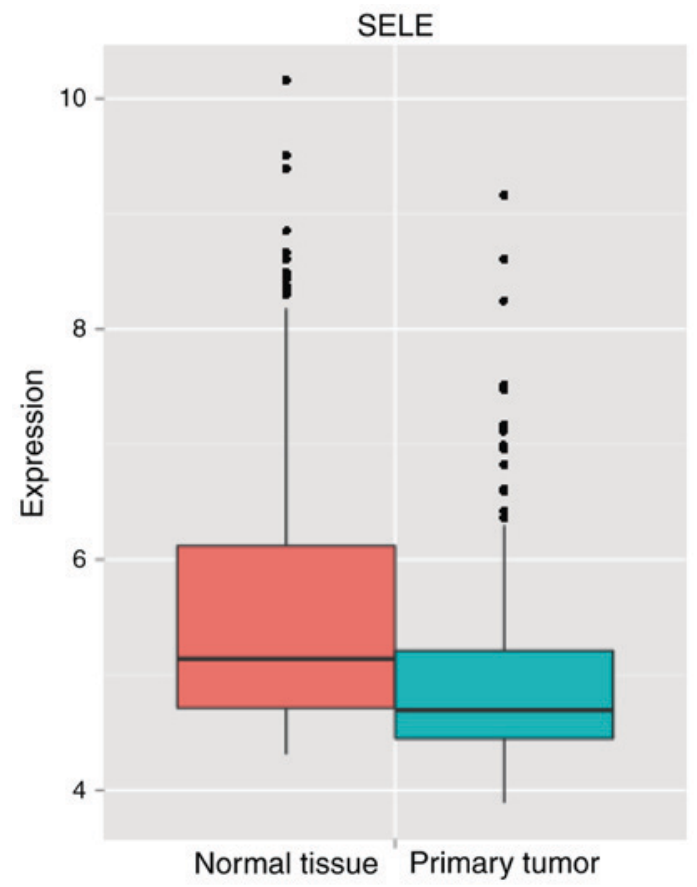

Figure 2. Expression profiles of endothelial selectin in breast cancer and normal tissues, determined using the Metabolic gEne RApid Visualizer. 
Table II. Correlation of endothelial selectin expression with overall survival in patients with breast cancer.

\begin{tabular}{|c|c|c|c|c|c|}
\hline Variable & Group & Cases & HR & $95 \% \mathrm{CI}$ & $\begin{array}{c}\text { Log-rank } \\
\text { P-value }\end{array}$ \\
\hline \multirow[t]{2}{*}{ ER status } & Positive & 548 & 0.72 & $0.50-1.03$ & 0.069 \\
\hline & Negative & 251 & 0.72 & $0.45-1.14$ & 0.160 \\
\hline \multirow[t]{2}{*}{ PR status } & Positive & 83 & 0.30 & $0.06-1.47$ & 0.120 \\
\hline & Negative & 89 & 1.36 & $0.54-3.44$ & 0.520 \\
\hline \multirow[t]{2}{*}{ HER2 status } & Positive & 252 & 0.81 & $0.52-1.25$ & 0.340 \\
\hline & Negative & 130 & 0.57 & $0.23-1.42$ & 0.220 \\
\hline \multirow[t]{2}{*}{ Lymph node status } & Positive & 313 & 0.76 & $0.51-1.12$ & 0.160 \\
\hline & Negative & 594 & 0.82 & $0.57-1.20$ & 0.310 \\
\hline \multirow[t]{3}{*}{ Grade } & 1 & 161 & 0.52 & $0.21-1.33$ & 0.170 \\
\hline & 2 & 387 & 0.63 & $0.41-0.98$ & 0.038 \\
\hline & 3 & 503 & 0.86 & $0.62-1.19$ & 0.350 \\
\hline \multirow[t]{4}{*}{ Intrinsic subtype } & Basal & 241 & 0.69 & $0.42-1.14$ & 0.140 \\
\hline & Luminal A & 611 & 0.70 & $0.49-1.01$ & 0.056 \\
\hline & Luminal B & 433 & 0.73 & $0.50-1.06$ & 0.095 \\
\hline & HER2+ & 117 & 0.77 & $0.40-1.48$ & 0.440 \\
\hline \multirow[t]{2}{*}{ TP53 status } & Mutated & 111 & 0.63 & $0.29-1.36$ & 0.230 \\
\hline & Wild type & 187 & 0.94 & $0.49-1.78$ & 0.840 \\
\hline \multirow[t]{6}{*}{ Pietenpol subtype } & Basal-like 1 & 58 & 0.83 & $0.28-2.48$ & 0.740 \\
\hline & Basal-like 2 & 38 & 2.80 & $0.72-10.85$ & 0.120 \\
\hline & Immunomodulatory & 100 & 0.78 & $0.31-1.97$ & 0.590 \\
\hline & Mesenchymal & 73 & 0.64 & $0.29-1.41$ & 0.270 \\
\hline & Mesenchymal stem-like & 19 & $\mathrm{~N} / \mathrm{A}$ & $\mathrm{N} / \mathrm{A}$ & N/A \\
\hline & Luminal androgen receptor & 83 & 1.01 & $0.52-1.99$ & 0.970 \\
\hline
\end{tabular}

HR, hazard ratio; CI, confidence interval; ER, estrogen receptor; PR, progesterone receptor; HER2, human epidermal growth factor 2; TP53, tumor protein $\mathrm{p} 53$; N/A, not available.

molecules by activated endothelial cells may possibly serve to 'block' counter ligands, for example on tumor cells, and subsequently prevent their adhesion to endothelial cells at metastatic sites (53). The significance of adhesion molecule shedding is not clear. They can also help adhesion molecules escape from the host defense mechanisms, thereby promoting dissemination and metastasis. Invasive $\mathrm{BC}$ cells resist host defense mechanisms only if they are able to survive. Madhavan et al (4) suggested that soluble ELAM1 could serve as an endothelial damage marker after activation by cytokines and the prompting of enhanced host defense mechanisms against the tumor. They pointed out that soluble ELAM1 was not a significant risk factor in patients with BC and nodal positivity. They suggested that the prognostic implications of soluble ELAM1 could be identified by survival analysis of long-term follow-up data from patients with BC. Thus, our findings do not conflict with data from previous studies $(12,13,17,19,21,22,25,29$, 50,51). The mechanism of serum ELAM1 release remains ambiguous, and the prognostic value of this marker is controversial $(4,19,22,25,27,28,30,31,51,54,55)$. An online analysis of tumor-dependent gene expression is essential to clarify the mechanisms involved. Our results confirmed that high ELAM1 mRNA expression in tumor specimens was a favorable factor for the prognosis of patients with BC.

Treatment has an important effect on the plasma level of ELAM1. Chemotherapeutic agents used for the treatment of $\mathrm{BC}$, including gemcitabine, anthracyclines, and vinca alkaloids $(21,56)$, may have endothelial toxicity and can cause endothelial cell apoptosis or necrosis in vitro (57). The plasma ELAM1 concentration is derived from endothelial damage following activation by cytokines. It may increase the serum ELAM1 concentration and interfere with the determination of the correlation between this concentration and BC prognosis. Moreover, intact endothelium is a prerequisite for normal functioning of the host defense system, and endothelial damage results in endothelial dysfunction. These factors may lead to the elevation of serum ELAM1 levels in patients with BC, worsening outcomes. The effects of soluble ELAM1 on host defense mechanisms and the promotion of tumor progression and metastasis are very complex.

ELAM1 is expressed in many cells other than endothelial cells, including lymphocytes, fibroblasts, and hematopoietic cells $(22,58,59)$. The concentration of soluble ELAM1 can be affected by conditions such as diabetes (52), arthritis (53), 
Table III. Correlation of endothelial selectin expression with relapse-free survival in patients with breast cancer.

\begin{tabular}{|c|c|c|c|c|c|}
\hline Variables & Group & Cases & HR & $95 \% \mathrm{CI}$ & $\begin{array}{c}\text { Log-rank } \\
\text { P-value }\end{array}$ \\
\hline \multirow[t]{2}{*}{ ER status } & Positive & 2,061 & 0.65 & $0.55-0.77$ & $<0.01$ \\
\hline & Negative & 801 & 0.79 & $0.63-0.99$ & 0.04 \\
\hline \multirow[t]{2}{*}{ PR status } & Positive & 589 & 0.58 & $0.40-0.83$ & $<0.01$ \\
\hline & Negative & 549 & 0.79 & $0.59-1.06$ & 0.12 \\
\hline \multirow[t]{2}{*}{ HER2 status } & Positive & 252 & 0.81 & $0.52-1.25$ & 0.34 \\
\hline & Negative & 800 & 0.53 & $0.40-0.70$ & $<0.01$ \\
\hline \multirow[t]{2}{*}{ Lymph node status } & Positive & 1,133 & 0.82 & $0.67-1.00$ & $<0.05$ \\
\hline & Negative & 2,020 & 0.73 & $0.62-0.87$ & $<0.01$ \\
\hline \multirow[t]{3}{*}{ Grade } & 1 & 345 & 0.59 & $0.34-1.01$ & 0.05 \\
\hline & 2 & 901 & 0.77 & $0.61-0.98$ & 0.03 \\
\hline & 3 & 903 & 0.76 & $0.61-0.94$ & 0.01 \\
\hline \multirow[t]{4}{*}{ Intrinsic subtype } & Basal & 618 & 0.67 & $0.52-0.86$ & $<0.01$ \\
\hline & Luminal A & 1,933 & 0.64 & $0.54-0.76$ & $<0.01$ \\
\hline & Luminal B & 1,149 & 0.69 & $0.57-0.83$ & $<0.01$ \\
\hline & HER 2+ & 251 & 0.9 & $0.61-1.32$ & 0.58 \\
\hline \multirow[t]{2}{*}{ TP53 status } & Mutated & 188 & 0.77 & $0.48-1.24$ & 0.28 \\
\hline & Wild type & 273 & 0.56 & $0.36-0.86$ & $<0.01$ \\
\hline \multirow[t]{6}{*}{ Pietenpol subtype } & Basal-like 1 & 171 & 0.9 & $0.56-1.45$ & 0.66 \\
\hline & Basal-like 2 & 76 & 1.09 & $0.54-2.21$ & 0.81 \\
\hline & Immunomodulatory & 203 & 0.53 & $0.29-0.98$ & 0.04 \\
\hline & Mesenchymal & 177 & 0.75 & $0.49-1.14$ & 0.18 \\
\hline & Mesenchymal stem-like & 63 & 1 & $0.46-2.20$ & 0.99 \\
\hline & Luminal androgen receptor & 203 & 0.96 & $0.64-1.44$ & 0.84 \\
\hline
\end{tabular}

HR, hazard ratio; CI, confidence interval; ER, estrogen receptor; PR, progesterone receptor; HER2, human epidermal growth factor 2; TP53, tumor protein $\mathrm{p} 53$.

cigarette smoking (60), chronic inflammatory syndromes (61), systemic infections (62), cardiovascular disease (63), and chronic renal failure (64). Chronic inflammation, an important factor in the development of $\mathrm{BC}$, has been shown to increase endothelial cell proliferation (65). For several reasons, obtaining reproducible correlations of serum ELAM1 levels with BC prognosis has been shown to be difficult $(4,19,21,22,25,27,28,30,31,51,54,55)$. The search for BC gene expression will be an accurate direction for prognosis estimation in the future.

Several limitations of this study must be recognized. Our data from the web-based tool were used only to perform univariate analysis; multivariate survival analysis using a Cox proportional-hazards regression model was not performed because of the incompletes of clinical KM-plot data. However, the prognostic evaluation of individual genes was based on data from 3,951 patients with $\mathrm{BC}$, and the results were consistent with those from the MERAV database. Our results provide insight into the association between ELAMI and $\mathrm{BC}$ prognosis.

In conclusion the use and development of ELAM1 mRNA as a predictive factor for BC will definitely benefit clinicians. Further investigation with well-designed studies and large samples is essential to validate our results.

\section{Acknowledgements}

Not applicable.

\section{Funding}

This study was supported by the National Natural Science Foundation of China (grant nos. 81260334, 81760533 and 81760517), Guangxi Science and Technology Department research programs (grant no. 14124004-1-11) and International Communication of Guangxi Medical University Graduate Education (2017).

\section{Availability of data and materials}

The datasets used and/or analyzed during the current study are available from the corresponding author on reasonable request.

\section{Authors' contributions}

DS designed the research; WZ wrote the manuscript; WZ, ZZ and XH collected the data; JL and GJ analyzed the data, and 
Table IV. Correlation of endothelial selectin expression with distant metastasis-free survival in patients with breast cancer.

\begin{tabular}{|c|c|c|c|c|c|}
\hline Variables & Group & Cases & HR & $95 \% \mathrm{CI}$ & $\begin{array}{c}\text { Log-rank } \\
\text { P-value }\end{array}$ \\
\hline \multirow[t]{2}{*}{ ER status } & Positive & 664 & 0.67 & $0.47-0.94$ & 0.02 \\
\hline & Negative & 218 & 0.82 & $0.52-1.30$ & 0.40 \\
\hline \multirow[t]{2}{*}{ PR status } & Positive & 192 & 0.49 & $0.20-1.19$ & 0.11 \\
\hline & Negative & 154 & 0.73 & $0.41-1.32$ & 0.30 \\
\hline \multirow[t]{2}{*}{ HER2 status } & Positive & 126 & 0.53 & $0.27-1.03$ & 0.06 \\
\hline & Negative & 150 & 0.22 & $0.07-0.65$ & $<0.01$ \\
\hline \multirow[t]{2}{*}{ Lymph node status } & Positive & 382 & 0.84 & $0.57-1.24$ & 0.38 \\
\hline & Negative & 988 & 0.84 & $0.64-1.10$ & 0.21 \\
\hline \multirow[t]{3}{*}{ Grade } & 1 & 188 & 0.88 & $0.38-2.07$ & 0.77 \\
\hline & 2 & 546 & 0.78 & $0.55-1.11$ & 0.16 \\
\hline & 3 & 458 & 1.02 & $0.72-1.44$ & 0.91 \\
\hline \multirow[t]{4}{*}{ Intrinsic subtype } & Basal & 232 & 0.69 & $0.41-1.15$ & 0.15 \\
\hline & Luminal A & 965 & 0.86 & $0.64-1.15$ & 0.30 \\
\hline & Luminal B & 430 & 0.7 & $0.49-1.01$ & 0.05 \\
\hline & HER2+ & 119 & 0.84 & $0.45-1.56$ & 0.57 \\
\hline \multirow[t]{2}{*}{ TP53 status } & Mutated & 83 & 1.08 & $0.45-2.59$ & 0.87 \\
\hline & Wild type & 109 & 0.72 & $0.33-1.56$ & 0.40 \\
\hline \multirow[t]{6}{*}{ Pietenpol subtype } & Basal-like 1 & 65 & 0.88 & $0.34-2.29$ & 0.80 \\
\hline & Basal-like 2 & 39 & 1.09 & $0.41-2.92$ & 0.87 \\
\hline & Immunomodulatory & 96 & 0.49 & $0.19-1.25$ & 0.13 \\
\hline & Mesenchymal & 65 & 1.06 & $0.44-2.55$ & 0.89 \\
\hline & Mesenchymal stem-like & 17 & $\mathrm{~N} / \mathrm{A}$ & N/A & $\mathrm{N} / \mathrm{A}$ \\
\hline & Luminal androgen receptor & 82 & 0.46 & $0.21-1.02$ & 0.05 \\
\hline
\end{tabular}

HR, hazard ratio; CI, confidence interval; ER, estrogen receptor; PR, progesterone receptor; HER2, human epidermal growth factor 2; TP53, tumor protein $\mathrm{p} 53$; N/A, not available.

GJ modified the manuscript. All authors gave final approval of this submission.

\section{Ethics approval and consent to participate}

The study was reviewed and approved by the Affiliated Tumor Hospital of Guangxi Medical University Institutional Review Board.

\section{Consent for publication}

Not applicable.

\section{Competing interests}

The authors declare that they have no competing interests.

\section{References}

1. Li XJ, Ren ZJ, Tang JH and Yu Q: Exosomal microRNA miR-1246 promotes cell proliferation, invasion and drug resistance by targeting CCNG2 in breast cancer. Cell Physiol Biochem 44: 1741-1748, 2017.

2. Wang K, Huang Q, Qiu F and Sui M: Non-viral delivery systems for the application in p53 cancer gene therapy. Curr Med Chem 22: 4118-4136, 2015.
3. Xiao J, Mu J, Liu T and Xu H: Dig the root of cancer: Targeting cancer stem cells therapy. J Med Discov 2: jmd17003, 2017.

4. Madhavan M,Srinivas P,Abraham E, Ahmed I, VijayalekshmiNR and Balaram P: Down regulation of endothelial adhesion molecules in node positive breast cancer: Possible failure of host defence mechanism. Pathol Oncol Res 8: 125-128, 2002.

5. Zhang W, Jin GQ, Liu JJ, Su DK, Luo NB, Xie D, Lai SL, Huang XY and Huang WL: Diagnostic performance of ADCs in different ROIs for breast lesions. Int J Clin Exp Med 8: 12096-12104, 2015.

6. Silva HC, Garcao F, Coutinho EC, De Oliveira CF and Regateiro FJ: Soluble VCAM-1 and E-selectin in breast cancer: Relationship with staging and with the detection of circulating cancer cells. Neoplasma 53: 538-543, 2006.

7. Xu YC, Zhang FC, Li JJ, Dai JQ, Liu Q, Tang L, Ma Y, Xu Q, Lin XL, Fan HB and Wang HX: RRM1, TUBB3, TOP2A, CYP19A1, CYP2D6: Difference between mRNA and protein expression in predicting prognosis of breast cancer patients. Oncol Rep 34: 1883-1894, 2015.

8. Luo P, Lu G, Fan LL, Zhong X, Yang H, Xie R, Lv Z, Lv QZ, Fu D, Yang LX and Ma Y: Dysregulation of TMPRSS3 and TNFRSF11B correlates with tumorigenesis and poor prognosis in patients with breast cancer. Oncol Rep 37: 2057-2062, 2017.

9. Zhang L, Chen Z, Xue D, Zhang Q, Liu X, Luh F, Hong L, Zhang H, Pan F, Liu Y, et al: Prognostic and therapeutic value of mitochondrial serine hydroxyl-methyltransferase 2 as a breast cancer biomarker. Oncol Rep 36: 2489-2500, 2016.

10. Harris L, Fritsche H, Mennel R, Norton L, Ravdin P, Taube S, Somerfield MR, Hayes DF and Bast RC Jr; American Society of Clinical Oncology: American society of clinical oncology 2007 update of recommendations for the use of tumor markers in breast cancer. J Clin Oncol 25: 5287-5312, 2007. 
11. Gyorffy B, Lanczky A, Eklund AC, Denkert C, Budczies J, Li Q and Szallasi Z: An online survival analysis tool to rapidly assess the effect of 22,277 genes on breast cancer prognosis using microarray data of 1,809 patients. Breast Cancer Res Treat 123: 725-731, 2010.

12. Koch AE, Halloran MM, Haskell CJ, Shah MR and Polverini PJ: Angiogenesis mediated by soluble forms of E-selectin and vascular cell adhesion molecule-1. Nature 376: 517-519, 1995

13. Gho YS, Kim PN, Li HC, Elkin M and Kleinman HK: Stimulation of tumor growth by human soluble intercellular adhesion molecule-1. Cancer Res 61: 4253-4257, 2001.

14. Price JT and Thompson EW: Mechanisms of tumour invasion and metastasis: Emerging targets for therapy. Expert Opin Ther Targets 6: 217-233, 2002 .

15. Pauli BU, Augustin-Voss HG, el-Sabban ME, Johnson RC and Hammer DA: Organ-preference of metastasis. The role of endothelial cell adhesion molecules. Cancer Metastasis Rev 9: 175-189, 1990.

16. Byrne GJ, Ghellal A, Iddon J, Blann AD, Venizelos V, Kumar S, Howell A and Bundred NJ: Serum soluble vascular cell adhesion molecule-1: Role as a surrogate marker of angiogenesis. J Natl Cancer Inst 92: 1329-1336, 2000.

17. Sheen-Chen SM, Eng HL, Huang CC and Chen WJ: Serum levels of soluble E-selectin in women with breast cancer. Br J Surg 91: $1578-1581,2004$

18. Gutman M and Fidler IJ: Biology of human colon cancer metastasis. World J Surg 19: 226-234, 1995.

19. O'Hanlon DM, Fitzsimons H, Lynch J, Tormey S, Malone C and Given HF: Soluble adhesion molecules (E-selectin, ICAM-1 and VCAM-1) in breast carcinoma. Eur J Cancer 38: 2252-2257, 2002.

20. Menger MD and Vollmar B: Adhesion molecules as determinants of disease: From molecular biology to surgical research. Br J Surg 83: 588-601, 1996.

21. Tesarova $P$, Kalousova M, Zima T, Suchanek M, Malikova I, Kvasnicka J, Duskova D, Tesar V, Vachek J, Krupickova-Kasalova Z and Malik J: Endotelial activation and flow-mediated vasodilation in young patients with breast cancer. Neoplasma 60: 690-697, 2013

22. Bewick M, Conlon M, Lee H, Parissenti AM, Zhang L, Glück S and LaFrenie RM: Evaluation of SICAM-1, sVCAM-1 and sE-Selectin levels in patients with metastatic breast cancer receiving high-dose chemotherapy. Stem Cells Dev 13: 281-294, 2004.

23. McEver RP: Selectin-carbohydrate interactions during inflammation and metastasis. Glycoconj J 14: 585-591, 1997.

24. Bevilacqua MP, Pober JS, Mendrick DL, Cotran RS and Gimbrone MA Jr: Identification of an inducible endothelial-leukocyte adhesion molecule. Proc Natl Acad Sci USA 84: 9238-9242, 1987.

25. Eichbaum MH, de Rossi TM, Kaul S and Bastert G: Serum levels of soluble E-selectin are associated with the clinical course of metastatic disease in patients with liver metastases from breast cancer. Oncol Res 14: 603-610, 2004.

26. Yasmin-Karim S, King MR, Messing EM and Lee YF: E-selectin ligand-1 controls circulating prostate cancer cell rolling/adhesion and metastasis. Oncotarget 5: 12097-12110, 2014.

27. Steinbach F, Tanabe K, Alexander J, Edinger M, Tubbs R, Brenner W, Stöckle M, Novick AC and Klein EA: The influence of cytokines on the adhesion of renal cancer cells to endothelium. J Urol 155: 743-748, 1996.

28. Daneker GW, Lund SA, Caughman SW, Staley CA and Wood WC: Anti-metastatic prostacyclins inhibit the adhesion of colon carcinoma to endothelial cells by blocking E-selectin expression. Clin Exp Metastasis 14: 230-238, 1996.

29. Nguyen M, Corless CL, Kraling BM, Tran C, Atha T, Bischoff $\mathrm{J}$ and Barsky SH: Vascular expression of E-selectin is increased in estrogen-receptor-negative breast cancer: A role for tumor-cell-secreted interleukin-1 alpha. Am J Pathol 150: 1307-1314, 1997.

30. Narita T, Kawakami-Kimura N, Matsuura N, Hosono J and Kannagi R: Corticosteroids and medroxyprogesterone acetate inhibit the induction of E-selectin on the vascular endothelium by MDA-MB-231 breast cancer cells. Anticancer Res 15: 2523-2527, 1995.

31. Gearing AJ, Hemingway I, Pigott R, Hughes J, Rees AJ and Cashman SJ: Soluble forms of vascular adhesion molecules, E-selectin, ICAM-1 and VCAM-1: pathological significance. Ann N Y Acad Sci 667: 324-331, 1992.
32. Olivotto IA, Bajdik CD, Ravdin PM, Speers CH, Coldman AJ, Norris BD, Davis GJ, Chia SK and Gelmon KA: Population-based validation of the prognostic model ADJUVANT! for early breast cancer. J Clin Oncol 23: 2716-2725, 2005.

33. Ravdin PM, Siminoff LA, Davis GJ, Mercer MB, Hewlett J, Gerson N and Parker HL: Computer program to assist in making decisions about adjuvant therapy for women with early breast cancer. J Clin Oncol 19: 980-991, 2001.

34. Gyorffy B, Lànczky $\mathrm{A}$ and Szàllàsi Z: Implementing an online tool for genome-wide validation of survival-associated biomarkers in ovarian-cancer using microarray data from 1287 patients. Endocr Relat Cancer 19: 197-208, 2012

35. Pénzvàltó $Z$, Lànczky $A$, Lénàrt $\mathrm{J}$, Meggyesházi $\mathrm{N}$, Krenács $\mathrm{T}$, Szoboszlai N, Denkert C, Pete I and Győrffy B: MEK1 is associated with carboplatin resistance and is a prognostic biomarker in epithelial ovarian cancer. BMC Cancer 14: 837, 2014.

36. Györffy B, Benke Z, Lànczky A, Balázs B, Szállási Z, Timár J and Schäfer R: RecurrenceOnline: An online analysis tool to determine breast cancer recurrence and hormone receptor status using microarray data. Breast Cancer Res Treat 132: 1025-1034, 2012.

37. Ivanova L, Zandberga E, Silina K, Kalnina Z, Ābols A, Endzelinš E, Vendina I, Romanchikova N', Hegmane A, Trapencieris $\mathrm{P}$, et al: Prognostic relevance of carbonic anhydrase IX expression is distinct in various subtypes of breast cancer and its silencing suppresses self-renewal capacity of breast cancer cells. Cancer Chemother Pharmacol 75: 235-246, 2015.

38. Tilghman SL, Townley I,Zhong Q, Carriere PP,Zou J, Llopis SD, Preyan LC, Williams CC, Skripnikova E, Bratton MR, et al: Proteomic signatures of acquired letrozole resistance in breast cancer: Suppressed estrogen signaling and increased cell motility and invasiveness. Mol Cell Proteomics 12: 2440-2455, 2013.

39. Zhou C, Zhong Q, Rhodes LV, Townley I, Bratton MR, Zhang Q, Martin EC, Elliott S, Collins-Burow BM, Burow ME and Wang G: Proteomic analysis of acquired tamoxifen resistance in MCF-7 cells reveals expression signatures associated with enhanced migration. Breast Cancer Res 14: R45, 2012.

40. Nieto-Jiménez C, Alcaraz-Sanabria A, Pàez R, Pérez-Peña J, Corrales-Sánchez V, Pandiella A and Ocaña A: DNA-damage related genes and clinical outcome in hormone receptor positive breast cancer. Oncotarget 8: 62834-62841, 2016.

41. Lànczky A, Nagy À, Bottai G, Munkácsy G, Szabó A, Santarpia L and Győrffy B: miR power: A web-tool to validate survival-associated miRNAs utilizing expression data from 2178 breast cancer patients. Breast Cancer Res Treat 160: 439-446, 2016.

42. Szàsz AM, Lànczky A, Nagy À, Förster S, Hark K, Green JE, Boussioutas A, Busuttil R, Szabó A and Győrffy B: Cross-validation of survival associated biomarkers in gastric cancer using transcriptomic data of 1,065 patients. Oncotarget 7: 49322-49333, 2016.

43. Shi X, Liang W, Yang W, Xia R and Song Y: Decorin is responsible for progression of non-small-cell lung cancer by promoting cell proliferation and metastasis. Tumour Biol 36: 3345-3354, 2015.

44. You Q, Guo H and Xu D: Distinct prognostic values and potential drug targets of ALDH1 isoenzymes in non-small-cell lung cancer. Drug Des Devel Ther 9: 5087-5097, 2015.

45. Shaul YD, Yuan B, Thiru P, Nutter-Upham A, McCallum S Lanzkron C, Bell GW and Sabatini DM: MERAV: A tool for comparing gene expression across human tissues and cell types. Nucleic Acids Res 44: D560-D566, 2016.

46. Kanehisa M, Goto S, Sato Y, Furumichi M and Tanabe M: KEGG for integration and interpretation of large-scale molecular data sets. Nucleic Acids Res 40 (Database Issue): D109-D114, 2012.

47. Borentain P, Carmona S, Mathieu S, Jouve E, El-Battari A and Gerolami R: Inhibition of E-selectin expression on the surface of endothelial cells inhibits hepatocellular carcinoma growth by preventing tumor angiogenesis. Cancer Chemother Pharmacol 77: 847-856, 2016.

48. Ben-David T, Sagi-Assif O, Meshel T, Lifshitz V, Yron I and Witz IP: The involvement of the sLe-a selectin ligand in the extravasation of human colorectal carcinoma cells. Immunol Lett 116: 218-224, 2008

49. Zwenger A, Rabassa M, Demichelis S, Grossman G, Segal-Eiras A and Croce MV: High expression of sLex associated with poor survival in Argentinian colorectal cancer patients. Int J Biol Markers 29: e30-e39, 2014. 
50. Geng Y, Yeh K, Takatani T and King MR: Three to tango: MUC1 as a ligand for both E-selectin and ICAM-1 in the breast cancer metastatic cascade. Front Oncol 2: 76, 2012.

51. Zhang GJ and Adachi I: Serum levels of soluble intercellular adhesion molecule-1 and E-selectin in metastatic breast carcinoma: Correlations with clinicopathological features and prognosis. Int J Oncol 14: 71-77, 1999.

52. Banks RE, Gearing AJ, Hemingway IK, Norfolk DR, Perren TJ and Selby PJ: Circulating intercellular adhesion molecule-1 (ICAM-1), E-selectin and vascular cell adhesion molecule-1 (VCAM-1) in human malignancies. Br J Cancer 68: 122-124, 1993.

53. Gearing AJ and Newman W: Circulating adhesion molecules in disease. Immunol Today 14: 506-512, 1993.

54. Hebbar M and Peyrat JP: Significance of soluble endothelial molecule E-selectin in patients with breast cancer. Int J Biol Markers 15: 15-21, 2000.

55. Muraki J, Kobayashi M, Sugaya Y, Hashimoto S, Morita T, Kobayashi Y and Tokue A: Role of serum E-selectin (ELAM-1) and inflammatory parameters in patients with renal cell carcinoma. Nihon Hinyokika Gakkai Zasshi 87: 831-841, 1996.

56. López-Miranda V, Herradón E, Gonzàlez C and Martín MI: Vascular toxicity of chemotherapeutic agents. Curr Vasc Pharmacol 8: 692-700, 2010.

57. Kaushal V, Kaushal GP and Mehta P: Differential toxicity of anthracyclines on cultured endothelial cells. Endothelium 11: 253-258, 2004

58. Ali S, Kaur J and Patel KD: Intercellular cell adhesion molecule-1, vascular cell adhesion molecule-1 and regulated on activation normal $\mathrm{T}$ cell expressed and secreted are expressed by human breast carcinoma cells and support eosinophil adhesion and activation. Am J Pathol 157: 313-321, 2000.

59. Ogawa Y, Hirakawa K, Nakata B, Fujihara T, Sawada T, Kato Y, Yoshikawa $\mathrm{K}$ and Sowa M: Expression of intercellular adhesion molecule-1 in invasive breast cancer reflects low growth potential, negative lymph node involvement and good prognosis. Clin Cancer Res 4: 31-36, 1998.
60. Cavusoglu Y, Timuralp B, Us T, Akgün Y, Kudaiberdieva G, Gorenek B, Unalir A, Goktekin O and Ata N: Cigarette smoking increases plasma concentrations of vascular cell adhesion molecule- 1 in patients with coronary artery disease. Angiology 55: 397-402, 2004.

61. Mason JC, Kapahi P and Haskard DO: Detection of increased levels of circulating intercellular adhesion molecule 1 in some patients with rheumatoid arthritis but not in patients with systemic lupus erythematosus. Lack of correlation with levels of circulating vascular cell adhesion molecule 1. Arthritis Rheum 36: 519-527, 1993.

62. Newman W, Beall LD, Carson CW, Hunder GG, Graben N, Randhawa ZI, Gopal TV, Wiener-Kronish J and Matthay MA: Soluble E-selectin is found in supernatants of activated endothelial cells and is elevated in the serum of patients with septic shock. J Immunol 150: 644-654, 1993.

63. Guray U, Erbay AR, Güray Y, Yilmaz MB, Boyaci AA, Sasmaz H, Korkmaz S and Kütük E: Levels of soluble adhesion molecules in various clinical presentations of coronary atherosclerosis. Int J Cardiol 96: 235-240, 2004.

64. Stenvinkel P, Lindholm B, Heimbürger M and Heimbürger O: Elevated serum levels of soluble adhesion molecules predict death in pre-dialysis patients: association with malnutrition, inflammation and cardiovascular disease. Nephrol Dial Transplant 15: 1624-1630, 2000.

65. Kuper H, Adami HO and Trichopoulos D: Infections as a major preventable cause of human cancer. J Intern Med 248: 171-183, 2000.

This work is licensed under a Creative Commons Attribution-NonCommercial-NoDerivatives 4.0 International (CC BY-NC-ND 4.0) License. 